\title{
UNSTRUCTURED KINETIC MODEL OF BATCH FERMENTATION OF USP GLYCEROL FOR LACTIC ACID PRODUCTION
}

\section{MODELO CINÉTICO NO-ESTRUCTURADO DE FERMENTACIÓN DISCONTINUA DE GLICEROL USP PARA LA PRODUCCIÓN DE ÁCIDO LÁCTICO}

\author{
Jimy-Alexander Gamboa-Ruedaㄹ, Víctor-Alexis Lizcano-González ${ }^{1}$, Mario-Andrés Ordoñez-Supelano², \\ José-Andrés Pérez-Mendoza ${ }^{3}$, Carolina Guzmán-Luna ${ }^{2}$ and Luis-Javier López-Giraldo ${ }^{4 *}$

\begin{abstract}
'Escuela de Ingeniería Química, Universidad Industrial de Santander, Bucaramanga, Santander, Colombia
${ }^{2}$ Escuela de Microbiología, Universidad Industrial de Santander, Bucaramanga, Santander, Colombia ${ }^{3}$ Programa de Ingeniería Química, Universidad del Atlántico, Barranquilla, Atlántico, Colombia ${ }^{4}$ Escuela de Ingeniería Química, Grupo de Investigación - CICTA, AgroBiotech Research Center-ABC, Universidad Industrial de Santander, Bucaramanga, Santander, Colombia
\end{abstract}

e-mail: lilopez@uis.edu.co

\section{ABSTRACT}

(Received: Feb. 06, 2015; Accepted: Jun. 02, 2015)

\begin{abstract}
his study show the capability of Lactobacillus rhamnosus ATCC 7469 to produce lactic acid using crude glycerol from biodiesel production as carbon source; in addition, a kinetic model that describes the behaviour of the fermentation process using USP glycerol as substrate was proposed and developed. The strain was adapted to the new carbon source by doing successive cultures, the substrate conversion was up to $94.5 \%$ after 24 hours of fermentation using crude glycerol as under initial conditions of substrate concentration (crude glycerol) and $\mathrm{pH}$ of $8 \mathrm{~g} / \mathrm{L}$ and 6.5 , respectively. Then, the influence of initial $\mathrm{pH}\left(\mathrm{pH}_{0}\right)$ and concentration of substrate $\left(S_{0}\right)$ were evaluated by fermentation tests of USP glycerol. The optimal value of volumetric lactic acid productivity $\left(Q_{v}\right)$ achieved from this study was $0.087 \mathrm{~g} \cdot \mathrm{L}^{-1} \cdot \mathrm{h}^{-1}$ for initial $\mathrm{pH}_{\circ}=6.5$ and initial substrate concentration $\mathrm{S}_{0}=6 \mathrm{~g} / \mathrm{L}$. Lastly, the kinetics parameters of an unstructured and not segregated model (Aiba type equation for growth rate expression), were adjusted with an average fit degree of $88 \%$ for all the initial conditions, using USP glycerol. In addition, the kinetic parameters are laid out as function of initial $\mathrm{pH}$ and substrate concentration.
\end{abstract}

Keywords: Inhibition, Crude glycerol, Kinetics, Lactobacillus rhamnosus, Fermentation, Lactic acid.

How to cite: Gamboa-Rueda, J. A., Lizcano-González, V. A., Ordoñez-Supelano, M. A., Pérez-Mendoza, J. A., GuzmánLuna, C. \& López-Giraldo, L. J. (2015). Unstructured kinetic model for batch fermentation of USP glycerol for lactic acid production. CT\&F - Ciencia, Tecnología y Futuro, 6(1), 81-94.

*To whom correspondence should be addressed 


\section{RESUMEN}

n este trabajo se demostró la capacidad de Lactobacillus rhamnosus ATCC 7469 para producir ácido
láctico usando glicerol crudo proveniente de la industria del biodiesel como fuente de carbono,
además se propuso y se desarrolló un modelo cinético que describe el proceso de fermentación usando
glicerol USP como sustrato. La cepa fue adaptada a la nueva fuente de carbono utilizando cultivos sucesivos,
la conversión de sustrato fue de hasta $94.5 \%$ después de 24 horas de fermentación en condiciones iniciales
de sustrato de $8 \mathrm{~g} / \mathrm{L}$ y $\mathrm{pH}$ inicial de 6.5 respectivamente. Posteriormente, la influencia del $\mathrm{pH}$ inicial $\left(\mathrm{pH} \mathrm{H}_{\mathrm{o}}\right.$ )
y la concentración de sustrato inicial $\left(\mathrm{S}_{\circ}\right)$ fueron evaluadas mediante ensayos fermentativos de glicerol USP.
El valor óptimo de productividad volumétrica de ácido láctico $\left(\mathrm{Q}_{\mathrm{v}}\right.$ ) alcanzado en este trabajo fue de 0.087
$\mathrm{g} \cdot \mathrm{L}^{-1} \cdot \mathrm{h}^{-1}$ para un $\mathrm{pH}$ inicial de $\mathrm{pH} \mathrm{H}_{\mathrm{o}}=6.5$ y una concentración inicial de sustrato $\mathrm{S}_{\circ}=6 \mathrm{~g} / \mathrm{L}$. Finalmente los
parámetros cinéticos de un modelo no estructurado y no segregado (ecuación tipo Aiba para la velocidad
de crecimiento), fueron optimizados alcanzando un grado de ajuste de $88 \%$ para todas las condiciones
iniciales, usando glicerol USP. Adicionalmente, los parámetros cinéticos son presentados como función del
$\mathrm{pH}$ inicial y la concentración inicial de sustrato.

Palabras clave: Inhibición, Glicerol crudo, Cinética, Lactobacillus rhamnosus, Fermentación, Ácido láctico

\section{RESUMO}

$\mathrm{E}$

ste trabalho demonstrou a capacidade do Lactobacillus rhamnosus ATCC 7469 para a produção de ácido láctico usando glicerol quando oriundo da indústria do biodiesel como fonte de carbono, adicionalmente, um modelo cinético foi proposto e desenvolvido com a finalidade de descrever o processo de fermentação usando glicerol USP como substrato. A cepa foi adaptada à nova fonte de carbono utilizando culturas sucessivas, a conversão do substrato foi de até $94.5 \%$ após 24 horas de fermentação em condições iniciais de substrato de $8 \mathrm{~g} / \mathrm{L} \mathrm{e} \mathrm{pH}$ inicial de 6.5, respectivamente. Posteriormente, a influência do $\mathrm{pH}$ inicial $\left(\mathrm{pH}_{0}\right)$ e a concentração de substrato inicial $\left(\mathrm{S}_{0}\right)$ foram avaliadas mediante ensaios fermentativos de glicerol USP. O valor ótimo de produtividade volumétrica de ácido láctico $\left(Q_{v}\right)$ conseguido neste trabalho foi de $0.087 \mathrm{~g} \cdot \mathrm{L}^{-1} \cdot \mathrm{h}^{-1}$ para um $\mathrm{pH}$ inicial de $\mathrm{pH}_{0}=6.5 \mathrm{e}$ uma concentração inicial de substrato $\mathrm{S}_{\mathrm{o}}=6 \mathrm{~g} / \mathrm{L}$. Finalmente, os parâmetros cinéticos de um modelo não estruturado e não segregado (equação tipo Aiba para a velocidade de crescimento), foram otimizados atingindo um grau de ajuste de $88 \%$ para todas as condições iniciais, usando glicerol USP. Adicionalmente, os parâmetros cinéticos são apresentados como função do pH inicial e a concentração inicial do substrato.

Palavras-chave: Inibição, Glicerol cru, Cinética, Lactobacillus rhamnosus, Fermentação, Ácido láctico. 


\section{INTRODUCTION}

The global production of biofuels (bioethanol and biodiesel) grew $0.7 \%$ from 2010 to 2011, with a remarkable increase of $7.32 \%$ in biodiesel production. Hence, the biodiesel industry in 2011 reached a production of $1.5 \times 10^{7}$ tons of equivalent oil (British Petroleum, 2012). In Colombia the biodiesel production was $4.4 \times 10^{5}$ metric tons, which represents an increase of $31.19 \%$ compared to 2010 (Fedebiocombustibles, 2012). The biodiesel process produces in average $10 \%$ in weight of glycerol (Posada, Rincón \& Cardona, 2012; Cerrate et al., 2006), which represented in 2011 an approximate production of crude glycerol of $4.9 \times 10^{4}$ tons in Colombia.

The overproduction of crude glycerol (industrial waste) and its low cost has prompted its use as raw material in other processes. Different biotechnological processes have been reported in which crude glycerol is converted into metabolites such as: 1,3-propanediol, citric acid, ethanol, buthanol (Dobson, Gray \& Rumbold, 2012) and polyhidroxialcanoates (Yáñez, 2013). Nevertheless, there are few studies where lactic acid is the main metabolite.

The biotechnological production of lactic acid from glycerol using Lactobacillus species is the result of several enzymatic steps. The first step is the formation of Glyceraldehide-3-Phospate (G3P) through glycerol dehydrogenation pathway and/or through glycerol dehydratase pathway. Lactobacillus rhamnosus ATCC 7469 only follows the dehydrogenation route, as it is shown in Figure 1 (Alvarez et al., 2004). Afterwards G3P is converted into pyruvate by glycolysis, finally pyruvate is dehydrogenated by the bacteria using the lactate dehydrogenase enzyme to produce lactic acid.

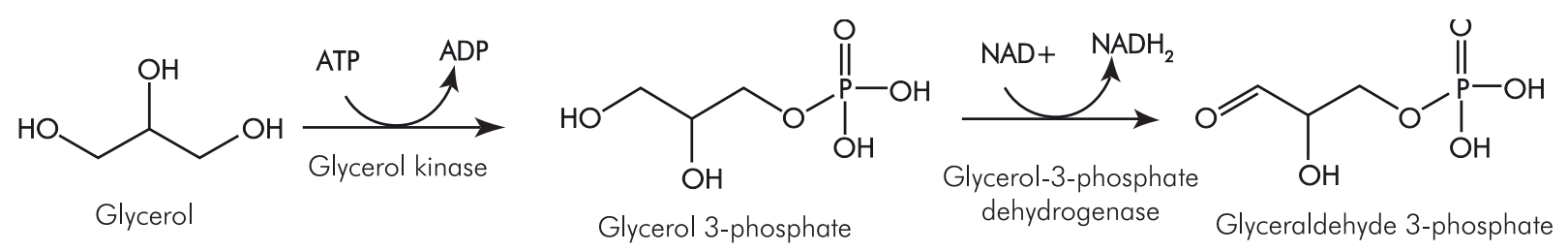

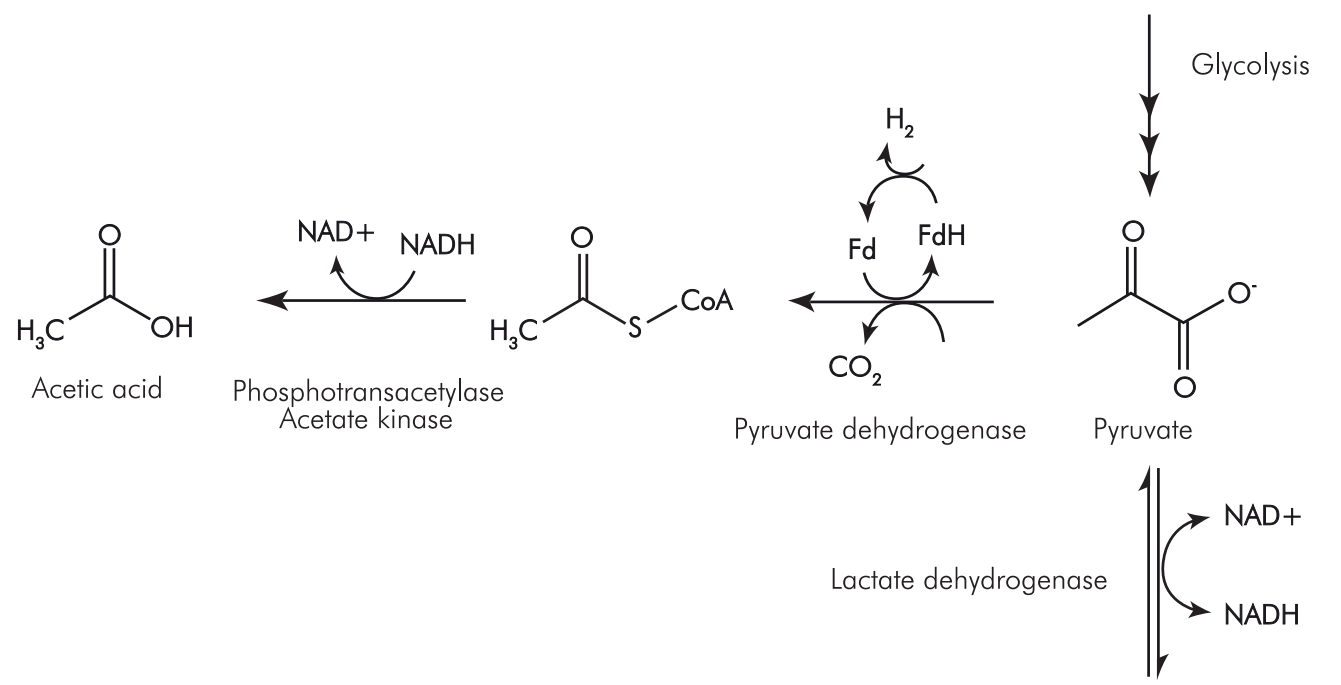<smiles>CC(O)C(=O)O</smiles>

Lactic acid

Figure 1.Lactic acid production in Lactobacillus rhamnosus ATCC 7469 through glycerol dehydrogenation pathway. Adapted from (Alvarez et al., 2004). 
This pathway is an innovative and competitive option due to the vast amount of applications of this organic acid in the food, pharmaceutical, cosmetic and chemical industries (Wee et al., 2005; Hofvendahl \& HahnHägerdal, 2000). Furthermore, the low cost of glycerol compared with glucose (common substrate used in the majority of fermentation processes that produce lactic acid) suggest that biotechnological processes for this kind of substrate are of great economic interest.

In this topic, Hong et al. (2009), determined optimal fermentation conditions for Escherichia coli AC-521 reaching lactic acid concentration up to $85.8 \mathrm{~g} / \mathrm{L}$ when fed-batch culture was applied with pure glycerol as carbon source. Choubisa et al. (2012), produced lactic acid from crude glycerol in batch cultures using strains of Lactobacillus delbrueckii reaching a concentration of $4.37 \mathrm{~g} / \mathrm{L}$ and from pure glycerol using Lactococcus lactis, reaching concentrations of $2.26 \mathrm{~g} / \mathrm{L}$. Mazumdar et al. (2013), working with a genetically modified Escherichia coli in fed-batch culture were able to produce lactic acid from crude glycerol with concentrations up to 50 $\mathrm{g} / \mathrm{L}$. In spite of these promising results, none of the aforementioned articles includes the development of a kinetic model of the process.

In order to design the fermenters and analyze the dynamic behavior (Almquist et al., 2014) of lactic acid production, the next step is the kinetic modeling of the fermentation process. Therefore, the development of microbial kinetic models with the capacity of describing and predicting the concentration of products, biomass and substrate during the process is required (Doran, 1995). Kinetic models can also be applied in the stability analysis of fermentation (Castellanos, Matallana \& López, 2014).

Although many different approaches could be used, in this study an unstructured and non-segregate model was selected in order to describe the fermentative system with a high degree of accuracy using the experimental information available (Banga, Versyck \& Van Impe, 2000; Berry et al., 1999; Pinelli et al., 1997; Zhang et al., 1998).

Lactobacillus rhamnosus ATCC 7469 was selected on the basis of (Alvarez et al., 2004):
1. It is possible to produce lactic acid from glycerol using this strain.

2. The metabolic pathway of this fermentation was described.

At a first stage and with the purpose of taking into account its possible industrial applicability, the capability of the strain to metabolize crude glycerol obtained from the biodiesel process nationwide was evaluated, without any pretreatment or a prior step of refining. Subsequently, an unstructured and not segregated kinetic model that describes the behavior of the USP glycerol fermentation to produce lactic acid was proposed, considering the influence of the initial substrate concentration and $\mathrm{pH}$. This proposed model would be a new approach because there are not available studies about the kinetic description for this specific type of fermentation.

\section{KINETIC MODEL FRAMEWORK}

Unstructured and not segregated models are defined as a differential equation system, which is based on the description of the specific growth rate $(\mu)$. This variable $\mu$ can be adjusted to different functions depending on different factors. In cases where inhibitor substrates and products are involved, the $\mu$ expression tends to be based on one of the following common models (Doran, 1995; Napoli et al., 2011; Shuler \& Kargi, 2009):

$\begin{array}{ll}\text { Ierusalimsky-type } & \mu=\mu_{m} \frac{S}{S+k_{s}} \frac{1}{1+P / k_{p}} \\ \text { Aiba-type } & \mu=\mu_{m} \frac{S}{S+k_{s}} \exp \left(-\frac{P}{k_{p}}\right) \\ \text { Luong-type } & \mu=\mu_{m} \frac{S}{S+k_{s}}\left(1-\frac{P}{P_{\max }}\right)^{n} \\ \text { Tessier-type } & \mu=-\mu_{m} * A+\mu_{m} * \exp \left(k_{s} * S\right)\end{array}$

The bacterial growth is usually described by: (Vlysidis et al., 2011).

$\frac{d x}{d t}=\mu * x$

The increasing product rate may be described by the Luedeking-Piret model (Vlysidis et al., 2011) considering growth and the non growth associated terms. 
$\frac{d P}{d t}=\left(\mu * y_{p / x}+m_{p}\right) * X$

Lastly, the substrate variation is constructed as a mass balance considering consumption for cell maintenance, product and biomass formation (Vlysidis et al., 2011).

$\frac{d S}{d t}=-\left(\frac{\mu}{y_{x / s}}+m_{S}\right) * X$

\section{MATERIALS AND METHODS}

\section{Reagents}

All the reagents used were of analytical grade, including liquid chromatography standards, salts for medium preparations, reagents for microbiological control etc. The crude glycerol was obtained from a Colombian biodiesel factory and its composition is detailed in Table 1 (Yáñez, 2013).

\section{Fermentation Cultures}

Man Rogosa Sharpe (MRS) media was used for growth and fermentation with the detailed formulation available in the microbiologic basic manual Cultimed (Panreac, 2012). In this research, glycerol (USP and crude) was used instead of glucose as carbon source. All cultures were carried out at $25 \mathrm{~mL}$ in $50 \mathrm{~mL}$ glass bottles, with $90 \% \mathrm{v} / \mathrm{v}$ of culture media and $10 \% \mathrm{v} / \mathrm{v}$ of inoculum with an Optical Density (OD) value of 0.2 units (the OD value is equivalent to an approximately start cell concentration of $10^{7} \mathrm{CFU} / \mathrm{mL}$ in the broth). The optical density was measured at $540 \mathrm{~nm}$ in a spectrophotometer GENESYS $^{\mathrm{TM}} 20$ (ThermoSpectronic). Fermentation conditions were set to $37^{\circ} \mathrm{C}$ and $200 \mathrm{rpm}$ in an orbital shaker Excella ${ }^{\mathbb{B}}$ E24 (New Brunswick Scientific).

\section{Microorganism and Adaptation to the New Carbon Source}

The strain Lactobacillus rhamnosus ATCC 7469 was purchased from the company Labcare de Colombia.
The adaptation to the new carbon source followed a series of consecutive cultures with a gradual increase of substrate concentration from $4 \mathrm{~g} / \mathrm{L}$ to $16 \mathrm{~g} / \mathrm{L}$. The bacterial cultures were intercalated between liquid and solid medium. Samples were taken after 24 hours in order to quantify the substrate conversion. Each test was done twice.

Effect of Initial $\mathrm{pH}$ and Substrate Concentration on the Volumetric Productivity

The effects of the initial conditions of $\mathrm{pH}\left(\mathrm{pH}_{\mathrm{o}}\right)$ and substrate concentration $\left(\mathrm{S}_{\mathrm{o}}\right)$ were evaluated following the experimental design shown in the Table 2.

Table 2. Experimental design for the USP glycerol fermentation.

\begin{tabular}{|c|cccc|}
\hline & \multicolumn{5}{c|}{ USP glycerol concentration (g/L) } \\
& & 6 & 8 & 10 \\
\hline $\mathrm{pH}_{0}$ & $5.5(\mathrm{~L})$ & $\mathrm{L} 6$ & $\mathrm{~L} 8$ & $\mathrm{~L} 10$ \\
\cline { 2 - 5 } & $6.5(\mathrm{H})$ & $\mathrm{H} 6$ & $\mathrm{H} 8$ & $\mathrm{H} 10$ \\
\hline
\end{tabular}

For all conditions, destructive assays were employed by triplicate. The monitoring was performed at $0,5,9$, 11,13 and 15 hours of fermentation. For all tests biomass concentration, lactic acid, glycerol concentration and $\mathrm{pH}$ were measured. Finally, the influence of the $\mathrm{pH}_{\mathrm{o}}$ and $\mathrm{S}_{\mathrm{o}}$ factors were studied through an ANOVA analysis having the volumetric productivity as the response variable; using software STATGRAPHICS ${ }^{\circledR}$ Centurion XV (trial version).

\section{Analytical Techniques Metabolites Monitoring}

Glycerol and lactic acid concentration were quantified through High Performance Liquid Chromatography (HPLC) using a Coregel $107 \mathrm{H}$ column coupled to a UFLC LC 20AD (Shimadzu) equipment; the detector was a refraction index detector RID-10A. The

Table 1. Composition and main physicochemical properties of crude glycerol (Yáñez, 2013).

\begin{tabular}{|c|c|c|c|c|c|c|c|}
\hline $\mathrm{pH}$ & $\begin{array}{l}\text { Density } \\
\text { (g/mL) }\end{array}$ & $\begin{array}{l}\text { Glycerol } \\
(\% \mathrm{w} / \mathrm{w})\end{array}$ & $\begin{array}{r}\text { Moisture } \\
\text { content } \\
(\% \mathrm{w} / \mathrm{w})\end{array}$ & $\begin{array}{c}\text { Ash } \\
(\% w / w)\end{array}$ & $\begin{array}{c}\text { Nitrogen } \\
\text { content }\end{array}$ & $\begin{array}{c}\text { Methanol } \\
(\% \mathrm{w} / \mathrm{w})\end{array}$ & $\begin{array}{l}\text { Soap } \\
\text { Content } \\
(\% w / w)\end{array}$ \\
\hline $6.414 \pm 0.124$ & $1.04 \pm 0.01$ & $51.43 \pm 0.23$ & $49.26 \pm 0.02$ & $2.85 \pm 0.25$ & Not detected & $3.57 \pm 0.05$ & $1.34 \pm 0.17$ \\
\hline
\end{tabular}


chromatography equipment was operated in isocratic mode at $80^{\circ} \mathrm{C}, 0.6 \mathrm{~mL} / \mathrm{min}$ flow. Sulfuric acid $8 \mathrm{~mm}$ was used as mobile phase. The analysis time was 25 minutes. Standards of the metabolites were used to calibrate the equipment. Prior to the analysis the samples were filtered using PVDF $0.45 \mu \mathrm{m}$ membranes.

\section{Biomass Monitoring}

The biomass quantification was done using the lineal relation between the dry weight and the optical density. To determine the dry weight, samples were taken at different times and centrifuged at $6000 \mathrm{rpm}$ during 15 minutes in a centrifuge MLW T23 (Janetski); afterwards the pellet was dried at $60^{\circ} \mathrm{C}$ until constant weight was reached.

\section{Kinetic Parameter Estimation}

First, for all conditions, the specific growth rate was calculated according to the Equation 8.

$\mu=\frac{1}{X} * \frac{d x}{d t}$

The function that describes the relation between the $\mu$ and the substrate concentration for all experiments was determined using the MATLAB's fmincon function operating an interior point algorithm as an optimization problem. The maintenance constants $\left(m_{s}, m_{p}\right)$ and the theoretical yields $\left(y_{x / s}, y_{p / x}\right)$ were calculated using Equations 9 and 10.

$$
\begin{aligned}
& \frac{1}{x} * \frac{d S}{d t}=-\left(\frac{1}{y_{x / s}} * \frac{1}{X} * \frac{d x}{d t}+m_{S}\right) \\
& \frac{1}{x} * \frac{d P}{d t}=\left(\frac{1}{x} * \frac{d x}{d t}+y_{p / S}+m_{S}\right)
\end{aligned}
$$

Subsequently the adjusted model was integrated using the ODE45 tool of the software MATLAB $\left(\right.$ MathWorks ${ }^{\circledR}$ ) 7.12.0 version. The parameters $y_{x / s}, k_{s}$ and $\mu_{m}$ were optimized using the fmincon function operating an interior point algorithm coupled to the previously mentioned integrator. Finally, the accuracy and validity of each model was evaluated by means of the correlation coefficient $\left(\mathrm{R}^{2}\right)$ and the average relative deviation, described in Equation 11.

Error $=\sum_{j=1}^{k} \sum_{j=1}^{m}\left|\frac{\text { Experimental-Theoretical }}{\text { Experimental }}\right| * \frac{100}{n}$

\section{RESULTS AND DISCUSSION}

\section{Strain Adaptation}

Adaptation process led to a better strain response to the new carbon source, which was represented in qualitative aspects as the number and size of the colonies in solid medium. It was also observed in quantitative aspects as the high grades of glycerol conversion reached (Figure 2).

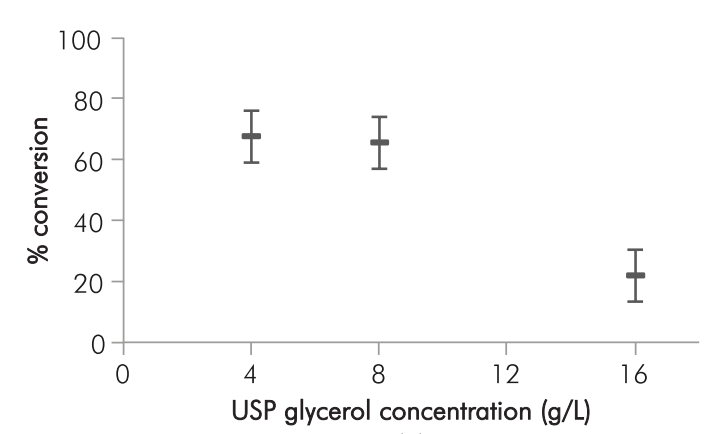

(a)

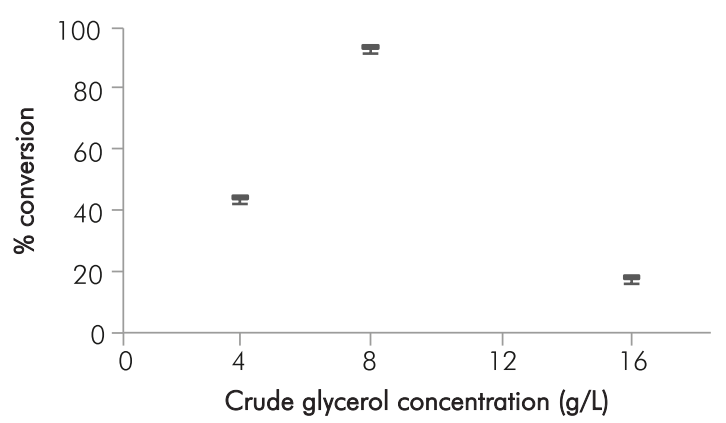

(b)

Figure 2. Means and Tukey HSD 95\% intervals for a) the USP glycerol conversion and b) crude glycerol.

Figure 2 shows that there is a significant conversion increase only when crude glycerol concentration was raised up from $4 \mathrm{~g} / \mathrm{L}$ to $8 \mathrm{~g} / \mathrm{L}$. It is remarkable the high percentage of crude glycerol conversion $(94.30 \pm 0.15)$. For $L$ rhamnosus ATCC 7469 both types of glycerol show substrate inhibition when concentration was raised up from $8 \mathrm{~g} / \mathrm{L}$ to $16 \mathrm{~g} / \mathrm{L}$. From the data shown in the Figure 2 it may be inferred that $L$. rhamnosus has the potential to consume both USP glycerol and crude glycerol to produce lactic acid. Furthermore, crude glycerol has a great potential as substrate in lactic acid production.

The fundamental hypothesis behind why crude glycerol showed higher conversion rates is that impurities 
like diglycerides, monoglycerides and some free fatty acids may act as nutrients and enhancers for microbial growth (Choubisa et al., 2012).

\section{Experimental Data for Kinetic Adjustment}

The experimental data was obtained following the experimental design described in the section 3. Profiles for substrate concentrations S (USP glycerol), biomass $\mathrm{x}$ (microorganisms) and product $\mathrm{P}$ (lactic acid) are shown in Figure 3.

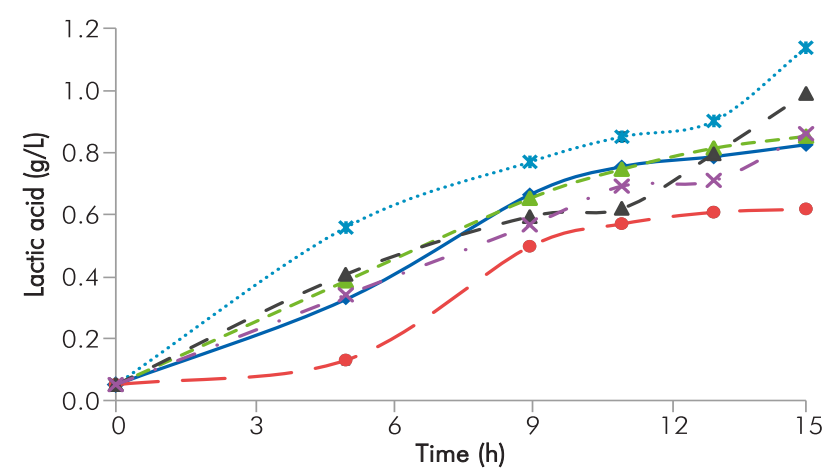

(a)

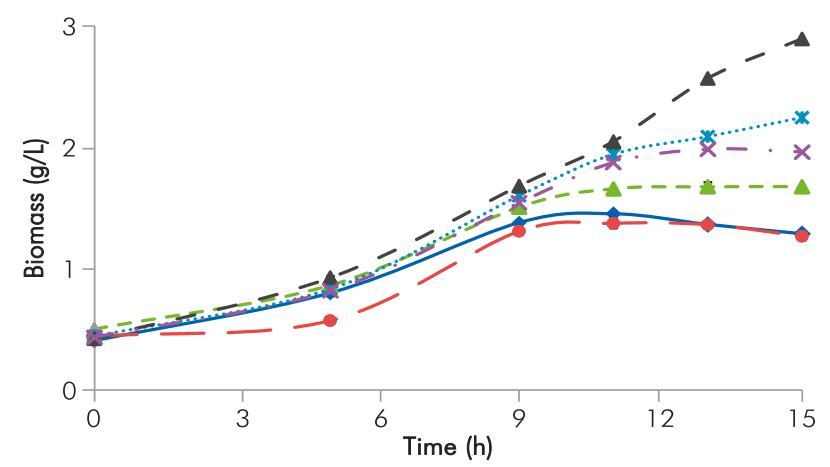

(b)

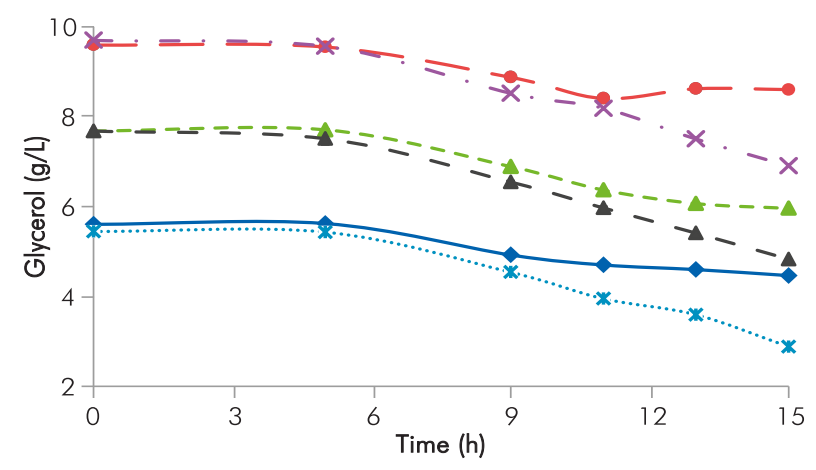

(c)

$\rightarrow \mathrm{L} 6-A-\mathrm{L} 8-\bullet \mathrm{L} 10 \cdots * \cdots \mathrm{H} 6-\Delta-\mathrm{H} 8-\mathrm{X} \cdot \mathrm{H} 10$

Figure 3. Profiles obtained for (a) product concentration $\mathrm{P}$, (b) biomas concentration $\mathrm{x}$ and (c) substrate concentration $\mathrm{S}$.
Figure $3 \mathrm{~b}$ shows a typical behavior of microorganisms, specifically there are two distinguishable patterns.

- Case 1: at low initial $\mathrm{pH} \quad\left(\mathrm{pH}_{0}=5.5\right.$; represented by the letter L) and all the initial substrate concentrations evaluated, the lag phase took $5 \mathrm{~h}$ approximately, the exponential growth zone length was $4 \mathrm{~h}$ approximately and the stationary phase started at $9 \mathrm{~h}$ of fermentation.

- Case 2: at high initial $\mathrm{pH}\left(\mathrm{pH}_{0}=6.5\right.$; represented by the letter $\mathrm{H}$ ) and all the initial substrate concentrations, the maximum exponential growth zone length was $10 \mathrm{~h}$ approximately and the stationary phase started after the 11 th $\mathrm{h}$ of fermentation.

It is clear that the exponential growth phase was longer for case 2, which allowed higher productions of lactic acid (Figure 3a) and higher conversion of glycerol (Figure 3c). These observations are consistent with the kinetics or dynamics (Equation 7) for substrate consumption involved in the production of primary metabolites as lactic acid.

It is remarkable that even when not detecting glycerol consumption (first 5 hours of fermentation), lactic acid production was detected indeed, which indicates that the strain has the ability to synthetize this metabolite using only the culture media (Figure $3 \mathrm{a}$ and $3 \mathrm{c}$ ). With regard to the above, it is known that some substances that are present in the MRS culture media such as peptone, yeast extract, meat extract and tween 80 , can be considered carbon sources (Garland \& Mills, 1991). A statistical data analysis was performed using the "Multiple response optimization" tool of the Statgraphics software (trial version). The maximum volumetric productivity calculated was $0.087 \mathrm{~g} \cdot \mathrm{L}^{-1} \cdot \mathrm{h}^{-1}$ for the initial conditions $\mathrm{pH}_{\mathrm{o}}=6.5$ and $\mathrm{S}_{\mathrm{o}}=6 \mathrm{~g} / \mathrm{L}$ and a fermentation time of 9.6 $\mathrm{h}$. This volumetric productivity is similar to the one obtained for Choubisa et al. (2012) using Lactobacillus delbrueckii $\left(0.091 \mathrm{~g} \cdot \mathrm{L}^{-1} \cdot \mathrm{h}^{-1}\right)$.

It should be noted that although the maximum glycerol conversion was around 50\%, this research was aimed to obtain the kinetic parameters of the process, which constitutes valuable information for further studies. These ideas and results are consistent with the study by Rivaldi et al. (2013). 


\section{Estimation of Kinetic Parameters}

This procedure has taken into account the exponential growth phase and it was conducted for all the initial conditions. The Figure 4a shows the relation between $\mu$ and glycerol concentration for the exponential growth phase in the H8 assay. The increasing tendency of the specific growth rate in relation to the glycerol concentration was similar for all assays. Equations 12 and 13 show modifications of the growth models of the Aiba and Tessier type (Shuler \& Kargi, 2009). These models were the ones that described the relation between $\mu$ and substrate concentration in the best way (see Figure $4 b$ ). Table 3 summarizes the values of the calculated parameters and the fit error for all the initial conditions.

$\mu=\frac{\mu_{m}}{1+\frac{k_{S}^{2}}{S^{2}}} * \exp \left(-\frac{P^{2}}{k_{p}^{2}}\right)$

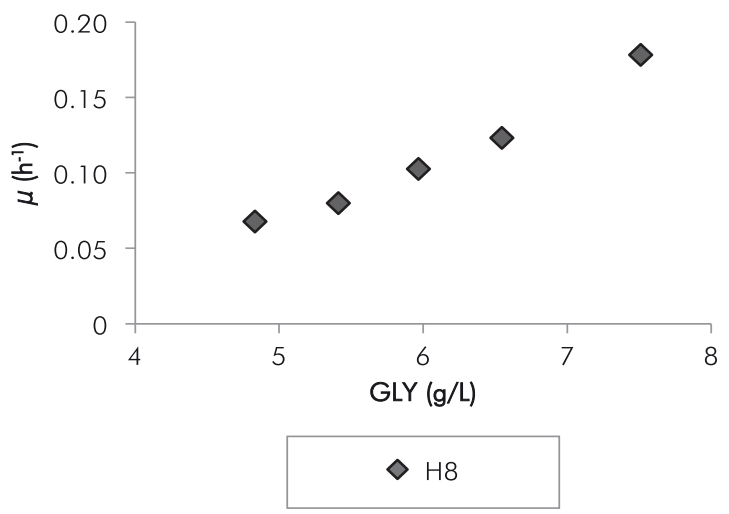

(a) $\mu=-\mu_{m} * A+\mu_{m} * \exp \left(k_{S}^{2} * S^{2}\right)$

From the results of adjustment, the following trends can be observed: For model 1 (Equation 12), in all cases studied, the maximum specific growth rate $\left(\mu_{m}\right)$ was greater for higher initial $\mathrm{pH}$. This trend is consistent with the results reported in Figure 3. Using model 2 (Equation 13) as fit model it is discarded because it is not possible to make a physical analysis of the fermentation, in addition, the mean absolute error was higher than the one in model 1.

The kinetic-stoichiometric parameters $y_{x / s}, m_{s}, y_{p / x}$ and $m_{p}$ were calculated applying a linear regression to Equations 8 and 9, as it was explained in section 3. Values are presented in Table 4 . The microorganism parameters were integrated to the differential Equations

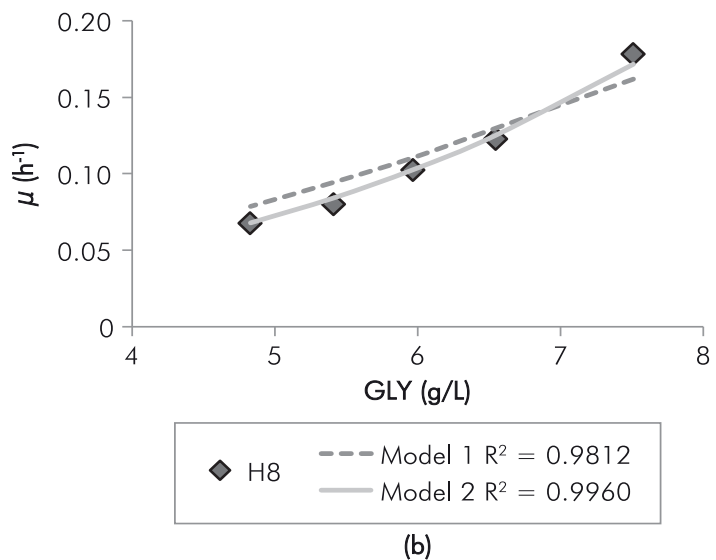

(b)

Figure 4. (a) Specific growth rate vs glycerol concentration for the H8 assay. (b) Plots of the proposed growth models.

Table 3. Estimated parameters for the models of specific growth rate.

\begin{tabular}{|c|c|c|c|c|c|c|c|c|}
\hline \multirow[b]{2}{*}{ Code } & \multicolumn{4}{|c|}{ Model 1} & \multicolumn{4}{|c|}{ Model 2} \\
\hline & $\mu_{m}\left(\mathrm{~h}^{-1}\right)$ & $k_{s}(g / L)$ & $k_{p}(g / L)$ & \% Error & $\mu_{m}\left(\mathrm{~h}^{-1}\right)$ & $k(g / L)$ & $A$ & \% Error \\
\hline L6 & 0.6839 & 5.0679 & 0.484 & $2.8 \mathrm{E}-6$ & 0.3755 & 0.1723 & 1.9188 & $3.4 \mathrm{E}-04$ \\
\hline $\mathrm{H} 6$ & 0.9809 & 2.3500 & 0.5362 & 0.7905 & 0.4696 & 0.1129 & 1.0918 & 9.8932 \\
\hline L8 & 0.9133 & 5.5129 & 0.4117 & 3.9887 & 0.2171 & 0.1113 & 1.5621 & 18.2032 \\
\hline $\mathrm{H} 8$ & 0.9838 & 17.0504 & 3.6427 & 4.0062 & 0.2246 & 0.0975 & 0.9462 & 2.0721 \\
\hline L10 & 0.6531 & 5.6328 & 0.2621 & $5.91 \mathrm{E}-4$ & 0.2605 & 0.1422 & 4.8695 & $4.41 \mathrm{E}-04$ \\
\hline $\mathrm{H} 10$ & 0.9473 & 10.8159 & 0.4663 & 13.55 & 0.2094 & 0.102 & 1.6862 & 19.1172 \\
\hline $\begin{array}{c}\text { Average } \\
\text { Error }\end{array}$ & & & & 1.69 & & & & 8.2141 \\
\hline
\end{tabular}


5-7, employing the model 1 of microbial growth (Table 3). To reduce the error of the proposed model in relation to the experimental values, the optimization of the $\mu_{m}$, $k_{s}$ and $y_{x / s}$ values was proposed, having as initial values the ones shown in Table 3 and Table 4.

Table 4. Theoretical yields, cell maintenance and product formation constants for all the initial conditions.

\begin{tabular}{|c|cccc|}
\hline \multicolumn{5}{|c|}{ Parameter } \\
\hline Code & $\begin{array}{c}y_{x / s} \\
\left(g \cdot g^{-1}\right)\end{array}$ & $\begin{array}{c}m_{s} \\
\left(g \cdot g^{-1} \cdot h^{-1}\right)\end{array}$ & $\begin{array}{c}y_{p / x} \\
\left(g \cdot g^{-1}\right)\end{array}$ & $\begin{array}{c}m_{p} \\
\left(g \cdot g^{-1} \cdot h^{-1}\right)\end{array}$ \\
\hline L6 & 0.6788 & 0.0062 & 0.5224 & 0.0117 \\
\hline H6 & 1.4043 & 0.0972 & 0.2323 & 0.0131 \\
\hline L8 & 0.2571 & 0.0201 & 0.3538 & 0.0098 \\
\hline H8 & 1.4407 & 0.029 & 0.2618 & 0.0018 \\
\hline L10 & 0.1662 & 0.0316 & 0.2149 & 0.0424 \\
\hline H10 & 3.073 & 0.1422 & 0.2202 & 0.0163 \\
\hline
\end{tabular}

Table 5 shows the post-optimization values for the kinetic parameters, the model error and the $\mathrm{R}^{2}$ coefficient value. As a result of parameter optimization it was possible to reduce the average error of the model from $31.53 \%$ to $12.24 \%$, hence the $\mathrm{R}^{2}$ value increased $6.55 \%$ in average (Table 5).
Figure 5 shows the integration of the not segregated and unstructured proposed model, using the optimized parameters for $\mathrm{H} 8$ assay. It is worth noting the grade of fit of the model for the $\mathrm{H} 8$ treatment, which represents an error of $9.3 \%$.

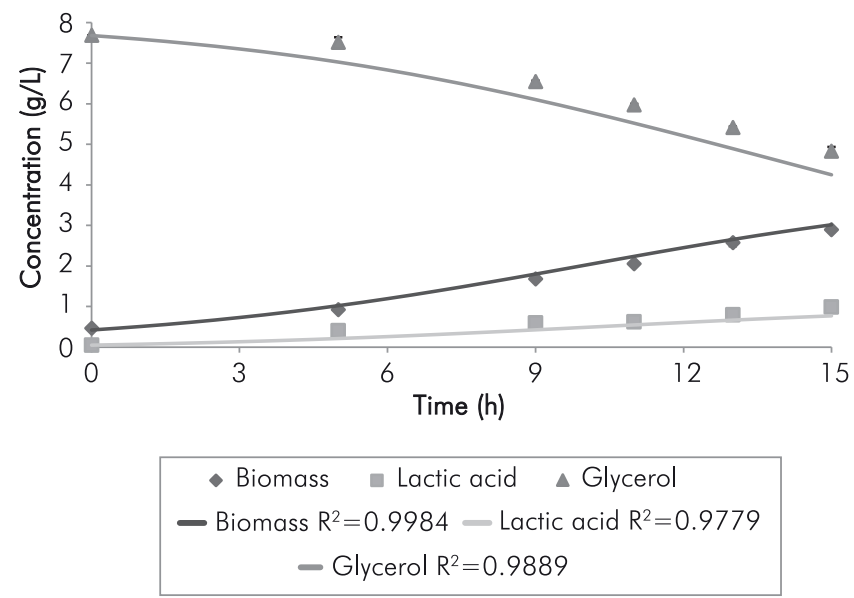

Figure 5. Profiles for lactic acid, glycerol and biomass concentration for the $\mathrm{H} 8$ assay using the optimized kinetic model.

According to the parameter obtained there are a directly proportional relation between the biomass substrate yield and the initial $\mathrm{pH}$ of the medium. That relation is inversely proportional in most of cases for the product-biomass yield. Theoretical yields $y_{x / s}$ greater than one could be explained partially by the fact that

Table 5. Kinetics parameters and error percentages pre and post-optimization using model 1.

\begin{tabular}{|c|c|c|c|c|c|c|c|c|}
\hline \multirow[b]{2}{*}{ Code } & \multirow[b]{2}{*}{$\begin{array}{c}\mu_{m} \\
\left(h^{-1}\right)\end{array}$} & \multirow[b]{2}{*}{$\begin{array}{c}k_{s} \\
\left(g \cdot L^{-1}\right)\end{array}$} & \multirow[b]{2}{*}{$\begin{array}{c}y x / s \\
\left(g \cdot g^{-1}\right)\end{array}$} & \multirow[b]{2}{*}{ Profiles } & \multicolumn{2}{|c|}{ Pre optimization } & \multicolumn{2}{|c|}{ Post optimization } \\
\hline & & & & & \% Error & $\mathrm{R}^{2}$ & $\%$ Error & $R^{2}$ \\
\hline L6 & 0.2146 & 0.1868 & 1.1847 & $\begin{array}{c}\text { Biomass } \\
\text { Substrate } \\
\text { Product }\end{array}$ & 16.6628 & $\begin{array}{l}0.9389 \\
0.8216 \\
0.9761\end{array}$ & 5.8631 & $\begin{array}{l}0.9569 \\
0.9149 \\
0.9927\end{array}$ \\
\hline $\mathrm{H} 6$ & 0.2501 & 2.5205 & 1.1999 & $\begin{array}{c}\text { Biomass } \\
\text { Substrate } \\
\text { Product }\end{array}$ & 70.2491 & $\begin{array}{l}0.7857 \\
0.8969 \\
0.9841\end{array}$ & 20.3907 & $\begin{array}{l}0.9866 \\
0.9649 \\
0.9732\end{array}$ \\
\hline L8 & 0.2605 & 3.9701 & 0.9712 & $\begin{array}{c}\text { Biomass } \\
\text { Substrate } \\
\text { Product }\end{array}$ & 25.6010 & $\begin{array}{c}0.874 \\
0.7192 \\
0.9734\end{array}$ & 9.1016 & $\begin{array}{l}0.9751 \\
0.9082 \\
0.9989\end{array}$ \\
\hline $\mathrm{H} 8$ & 0.2751 & 6.4763 & 1.1822 & $\begin{array}{l}\text { Biomass } \\
\text { Substrate } \\
\text { Product }\end{array}$ & 9.5161 & $\begin{array}{l}0.9973 \\
0.9874 \\
0.9789\end{array}$ & 9.3000 & $\begin{array}{l}0.9984 \\
0.9889 \\
0.9779\end{array}$ \\
\hline L10 & 0.2349 & 5.1493 & 0.8409 & $\begin{array}{l}\text { Biomass } \\
\text { Substrate } \\
\text { Product }\end{array}$ & 35.1270 & $\begin{array}{l}0.7382 \\
0.7007 \\
0.9485\end{array}$ & 17.1315 & $\begin{array}{l}0.8457 \\
0.8592 \\
0.9577\end{array}$ \\
\hline $\mathrm{H} 10$ & 0.2452 & 3.9218 & 1.194 & $\begin{array}{c}\text { Biomass } \\
\text { Substrate } \\
\text { Product }\end{array}$ & 32.0436 & $\begin{array}{l}0.9046 \\
0.9753 \\
0.9933\end{array}$ & 11.6248 & $\begin{array}{l}0.9847 \\
0.9768 \\
0.9937\end{array}$ \\
\hline $\begin{array}{c}\text { Average } \\
\text { Error }\end{array}$ & & & & & 31.5333 & & 12.2353 & \\
\hline
\end{tabular}



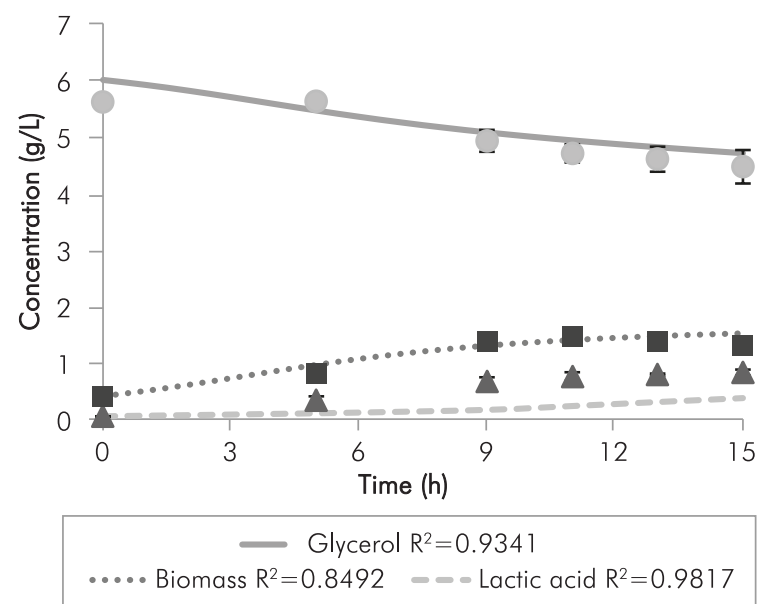

(a)

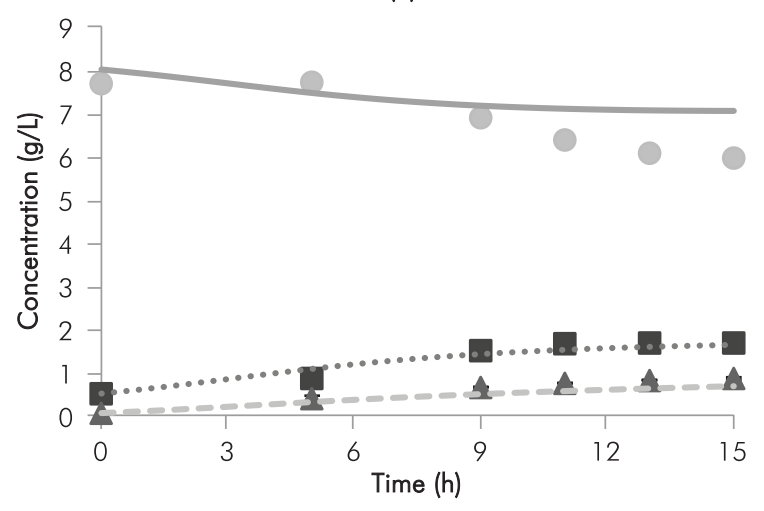

Glycerol $R^{2}=0.8703$

.... Biomass $R^{2}=0.9735 \quad \ldots$. Lactic acid $R^{2}=0.9988$

(c)

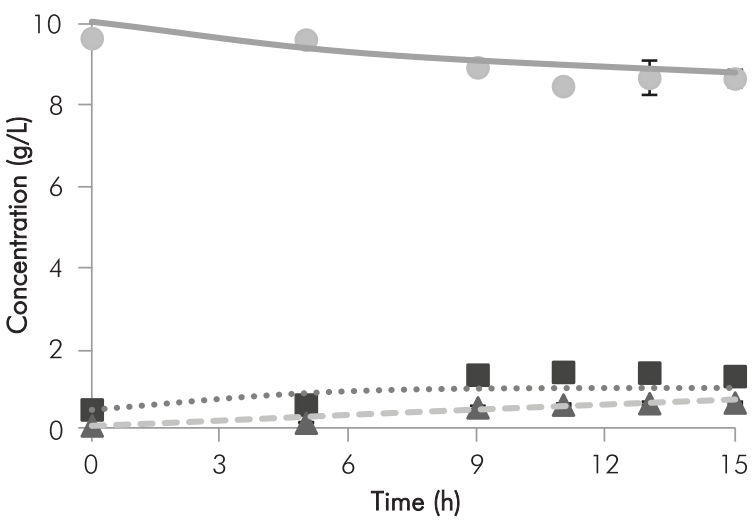

Glycerol $R^{2}=0.8956$

… Biomass $R^{2}=0.9007 \quad-$. Lactic acid $R^{2}=0.9611$

(e)

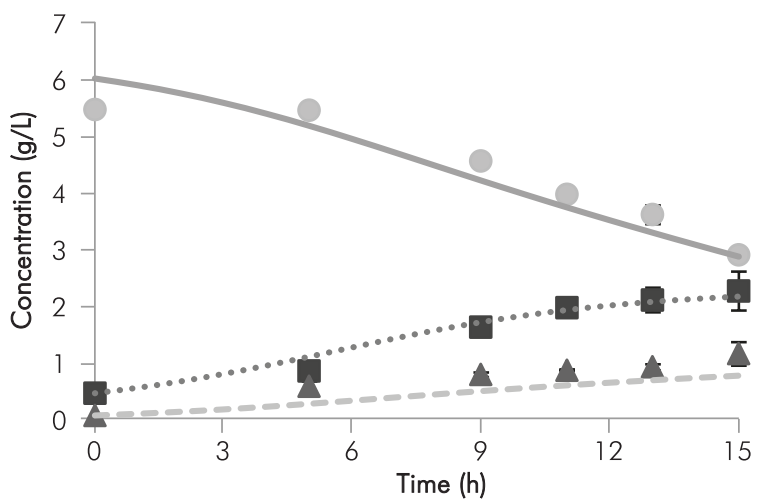

Glycerol $R^{2}=0.9591$

iomass $R^{2}=0.9737$ - Lactic acid $R^{2}=0.9731$

(b)
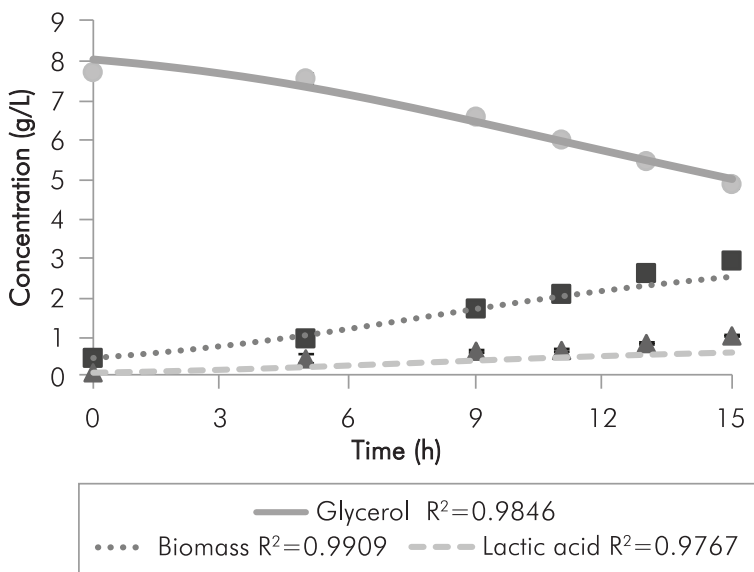

(d)

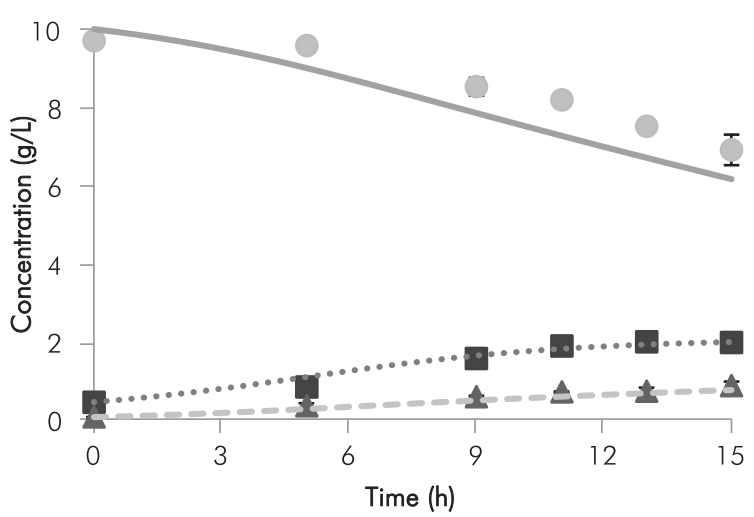

Glycerol $R^{2}=0.9792$
$\ldots$ Biomass $R^{2}=0.9889 \quad--$ Lactic acid $R^{2}=0.9935$

(f)

Glycerol Biomass $\triangle$ Lactic acid

Figure 6. Comparison between the kinetic model proposed and the experimental data for all initial conditions of $\mathrm{pH}$ and substrate concentration. (a)L6, (b) H6, (c)L8, (d) H8, (e)L1O, (f) H1O. 
this analysis does not separate the biomass formed from glycerol of the one formed just from the culture medium. The low values for the maintenance constants $\left(m_{s}\right.$ and $m_{p}$ ) have their explanation in the fact that for facultative anaerobic strain as it is L. rhamnosus ATCC 7469 these values are typically low or even negligible (Vlysidis et al., 2011). In the case of the inhibition constants $\left(k_{s}\right.$ and $k_{p}$ ) it is not possible to make an extensive discussion since there is not available information of kinetic studies of the same strain with the same carbon source, because of the novelty character of this research. However, it is possible to state that the order of magnitude is comparable with similar kinetic studies that have been using glycerol as carbon source or lactic acid as the main product. In this regard, the fitted values of $\mu_{\mathrm{m}}$ are in average $50 \%$ lower than the reported for glucose fermentation, which could be considered normal due to USP glycerol is a substrate more difficult to assimilate by microorganisms (Berry et al., 1999; Vlysidis et al., 2011).

To extend the applicability of the proposed model within the interval of established conditions, regression functions were developed in order to relate each parameter with the input variables $\mathrm{pH}_{\mathrm{o}}$ and $\mathrm{S}_{0}$, obtaining the functions shown in Equations 14 to 20.

Equations 14-20 regression functions of the kinetic parameters in respect to $\mathrm{pH}_{\mathrm{o}}$ and $\mathrm{S}_{\mathrm{o}}$

The integrated profiles for all the initial conditions using the previously described regression functions are shown in Figure 6. It becomes evident that the profiles are consistent with the trend that describe the physical behavior of the bioprocess, hence, showing the good fit that represents the kinetic model proposed with mean values for error of $12.45 \%$ and 0.955 for the $\mathrm{R}^{2}$.

\section{CONCLUSION}

Lactobacillus rhamnosus ATCC 7469 was able to assimilate crude glycerol successfully with a substrate conversion close to $95 \%$ after $24 \mathrm{~h}$ of fermentation. Additionally the substrate conversion (USP glycerol) and the lactic acid production were favored by high initial $\mathrm{pH}(6.5)$ and low glycerol concentration $(8 \mathrm{~g} / \mathrm{L})$. Hence, it was found evidence of a direct relation between the length of the exponential growth phase and the lactic acid concentration. For the initial conditions evaluated it was possible to identify that the optimum value for the volumetric productivity is around $9.6 \mathrm{~h}$ of fermentation with a value of $\mathrm{Q}_{\mathrm{v}}=0.087 \mathrm{~g} \cdot \mathrm{L}^{-1} \cdot \mathrm{h}^{-1}$. Finally, an unstructured and not segregated kinetics model that describes the fermentation process with a mean fit grade of $88 \%$ was proposed for the six initial conditions. It is noteworthy that the maximum glycerol conversion experimentally achieved was around fifty percent.

\section{ACKNOWLEDGEMENTS}

The authors wish to thank the Vicerrectoria de Investigación y Extensión of the Universidad Industrial de Santander for the financial support through the project entitled: Escalamiento de los procesos de producción de bio-alcoholes y procesamiento de subproductos provenientes de la producción de biocombustibles por via fermentativa (Code 5452), the Bacteriology school of the Universidad Industrial de Santander for all the locations and equipment provided, and the Chemical Engineering school for allowing us to conduct all the HPLC analysis.

$$
\begin{aligned}
& \mu_{m}=-0.6840+0.1672 S_{o}+0.0715 p H_{o}-0.0079 S_{o}{ }^{2}-0.0064 S_{o} p H_{o} \\
& k_{s}=-63.4388+11.9195 S_{o}+5.3646 p H_{o}-0.4903 S_{o}{ }^{2}-0.573 S_{o} p H_{o} \\
& k_{p}=1.2809-0.1261 S_{o}-0.1785 p H_{o}-0.0087 S_{o}{ }^{2}+0.038 \mathrm{~S}_{o} p H_{o} \\
& m_{s}=0.4844-0.1996 S_{o}+0.0309 p H_{o}+0.0112 S_{o}{ }^{2}+0.0049 S_{o} p H_{o} \\
& m_{p}=-0.0515-0.0148 S_{o}+0.0441 p H_{o}+0.0038 * S_{o}{ }^{2}-0.0069 S_{o} p H_{o} \\
& y_{x / s}=4.7734-0.6633 S_{o}-0.4827 p H_{o}-0.0070 S_{o}{ }^{2}+0.0845 S_{o} p H_{o} \\
& y_{p / x}=4.7602-0.4417 S_{o}-0.7164 p H_{o}-0.0026 S_{o}{ }^{2}+0.0745 S_{o} p H_{o}
\end{aligned}
$$




\section{REFERENCES}

Almquist, J., Cvijovic, M., Hatzimanikatis, V., Nielsen, J. \& Jirstrand, M. (2014). Kinetic models in industrial biotechnology - Improving cell factory performance. Metab. Eng., 24: 38-60.

Alvarez, M., Medina, R., Pasteris, S., Strasser de Saad, A. \& Sesma, F. (2004). Glycerol metabolism of Lactobacillus rhamnosus ATCC 7469: Cloning and expression of two glycerol kinase genes. J. Mol. Microbiol. Biotechnol., 7(4), 170-181.

Banga, J. R., Versyck, K. J. \& Van Impe, J. F. (2000). Numerical strategies for optimal experimental design for parameter identification of non-linear dynamic (Bio-) chemical processes. Comput. Aided Chem. Eng., 8: 37-42.

Berry, A., Franco, C., Zhang, W. \& Middelberg, A. (1999). Growth and lactic acid production in batch culture of Lactobacillus rhamnosus in a defined medium. Biotechnol. Letters. 21(2), 163-167.

British Petroleum. (2012). BP Statistical Review of World Energy., London, England. 45pp.

Castellanos, L. J., Matallana, L. G. \& López. L. J., (2014). Análisis de estabilidad de un sistema de fermentación acetona-butanol-etanol (ABE) a partir de glucosa empleando Clostridium acetobutylicum ATCC 824. Rev. Mutis, 4(1), 15-23.

Cerrate, S., Yan, F., Wang, Z., Coto, C., Sacakli, P. \& Waldroup, P. W. (2006). Evaluation of glycerine from biodiesel production as a feed ingredient for broilers. Int. J. Poult. Sci., 5(11), 1001-1007.

Choubisa, B., Patel, H., Patel, M. \& Dholakiya, B. (2012). Microbial production of lactic acid by using crude glycerol from biodiesel. J. Microbiol. Biotech. Res., 2(1), 90-93.

Dobson, R., Gray, V. \& Rumbold, K. (2012). Microbial utilization of crude glycerol for the production of valueadded products. J. Ind Microbiol. Biotechnol., 39(2), 217-226.

Doran, P. M. (1995). Bioprocess engineering principles. 1 ed. England: Elsevier Science and Technologic Books.

Federación Nacional de Biocombustibles de Colombia. (2012). Cifras informativas de sector biocombustibles, biodiésel de palma de aceite. Informe Fedebiocombustibles, Bogotá, Colombia. 8pp.

Garland, J. L. \& Mills, A. L. (1991). Classification and characterization of heterotrophic microbial communities on the basis of patterns of community-level sole-carbonsource utilization. Appl. Environ. Microbiol., 57(8), 2351-2359.

Hofvendahl, K. \& Hahn-Hägerdal, B. (2000). Factors affecting the fermentative lactic acid production from renewable resources. Enzyme Microbial Technol., 26(24), 87-107.

Hong, A. A., Cheng, K. K., Peng, F., Zhou, S., Sun, Y., Liu, C. M. \& Liu, D. H. (2009). Strain isolation and optimization of process parameters for bioconversion of glycerol to lactic acid. J. Chem. Technol. Biotechnol., 84(10), 15761581.

Mazumdar, S., Blankschien, M. D., Clomburg, J. M. \& Gonzalez, R. (2013). Efficient synthesis of L-lactic acid from glycerol by metabolically engineered Escherichia coli. Microb. Cell Fact., 12: 1-7

Napoli, F., Olivieri, G., Russo, M., Marzocchella, A. \& Salatino, P. (2011). Continuous lactose fermentation by Clostridium acetobutylicum-Assessment of acidogenesis kinetics. Bioresour. Technol. 102(2), 1608-1614.

Panreac. Cultimed (2012). Manual básico de microbiología. PANREAC.

Pinelli, D., González-Vara, A., Matteuzzi, D. \& Magelli, F. (1997). Assessment of kinetic models for production of L- and D- lactic acid isomers by Lactobacillus casei DMS 20011 and Lactobacillus coryniformis DMS 20004 in continuous fermentation. J. Ferment. Bioeng., 83(2), 209-212.

Posada, J. A., Rincón, L. E. \& Cardona, C. A. (2012). Design and analysis of biorefineries based on raw glycerol: Addressing the glycerol problem. Bioresour. Technol., 111: 282-293.

Rivaldi, J., Sousa, M., Duarte, L., Ferreira, A., Cordeiro, C., de Almeida, M., de Ponces, A. \& de Mancilha, I. (2013). Metabolism of biodiesel-derived glycerol in probiotic Lactobacillus strains. Appl. Microbiol. Biotechnol., 97(4), 1735-1743. 
Shuler, M. L. \& Kargi, F. (2009). Bioprocess engineering basic concepts. 2 ed. United States: Prentice Hall PTR.

Vlysidis, A., Binns, M., Webb, C. \& Theodoropoulos, C. (2011). Glycerol utilization for the production of chemicals: Conversion to succinic acid, a combined experimental and computational study. Biochem. Eng. J. 58-59: 1-11.

Yáñez, C. (2013). Extracción y caracterización de polihidroxibutirato producido a partir de Bacillus megaterium ATCC 14581 utilizando glicerol residuo de la industria de biodiesel como fuente de carbono. Tesis de pregrado, Escuela de Química, Universidad Industrial de Santander, Bucaramanga, Colombia, 63pp.

Wee, Y. J., Kim, J. N., Yun, J. S. \& Ryu, H. W. (2005). Optimum conditions for the biological production of lactic acid by a newly isolated lactic acid bacterium, Lactobacillus sp. RKY2. Biotechnol. Bioprocess Eng., 10(1), 23-28.

Zhang, X. W., Sun, T., Sun, Z. Y., Liu, X. \& Gu, D. X. (1998). Time-dependent kinetic models for glutamic acid fermentation. Enzyme Microbiol. Technol., 22(3), 205-209.

\section{AUTHORS}

\section{Jimy-Alexander Gamboa-Rueda}

Affiliation: Universidad Industrial de Santander

Chemical Engineering, Universidad Industrial de Santander

e-mail: jimygamboa@gmail.com

\section{Víctor-Alexis Lizcano-González}

Affiliation: Universidad Industrial de Santander

e-mail: victorlizcano@outlook.com

\section{Mario-Andrés Ordoñez-Supelano}

Affiliation: Universidad Industrial de Santander

e-mail: mario.ordonhez@gmail.com

\section{José-Andrés Pérez-Mendoza}

Affiliation: Universidad del Atlántico

Chemical Engineering, Universidad Industrial de Santander

M. Sc. Chemistry, Universidad Industrial de Santander

e-mail: jandrespmen@gmail.com

\section{Carolina Guzmán-Luna}

Affiliation: Universidad Industrial de Santander Bacteriologist, Universidad Industrial de Santander e-mail: cgluna74@gmail.com

\section{Luis-Javier López-Giraldo}

Affiliation: Universidad Industrial de Santander Chemical Engineer, Universidad Nacional de Colombia Ph. D. in Chemistry, Biochemistry and Food Science, École Superieur Agronomique Montpellier e-mail: 1jlopez@uis.edu.co 


\section{NOTATION}

$\mathrm{pH}_{o} \quad$ Initial $\mathrm{pH}$

$S_{o} \quad$ Initial substrate concentration, $\mathrm{g} / \mathrm{L}$

$Q_{v} \quad$ Volumetric productivity, $\mathrm{g} \cdot \mathrm{L}^{-1} \cdot \mathrm{h}^{-1}$

$\mu \quad$ Specific growth rate, $\mathrm{h}^{-1}$

$\mu_{m} \quad$ The maximum specific growth rate, $\mathrm{h}^{-1}$

$S \quad$ Substrate concentration, g/L

$k_{s} \quad$ Saturation constant, $\mathrm{g} / \mathrm{L}$

$P \quad$ Product concentration, $\mathrm{g} / \mathrm{L}$

$k_{p} \quad$ Product inhibition constant, g/L

n Empirical constant

A Empirical constant

$x \quad$ Biomass concentration, $\mathrm{g} / \mathrm{L}$

$y \quad$ Theoretical yield, $\mathrm{g} / \mathrm{g}$

$m_{p} \quad$ Non growth associated product formation constant, $\mathrm{g} \cdot \mathrm{g}^{-1} \cdot \mathrm{h}^{-1}$

$m_{s} \quad$ Maintenance substrate consumption, $\mathrm{g} \cdot \mathrm{g}^{-1} \cdot \mathrm{h}^{-1}$

$k \quad$ Total number of measured variables

$m \quad$ Number of data measured in the exponetia phase of growth for each variable 